\title{
Effects of soil management regimes on biochemical properties of a loess soil
}

\author{
S. Zhang ${ }^{1,2}$, H. Li ${ }^{2}$, X. Yang ${ }^{2}$, B. Sun ${ }^{2}$ \\ ${ }^{1}$ State Key Laboratory of Soil Erosion and Dryland Farming, Northwest A \& F University, Yangling, 712100, \\ Shaanxi, China ${ }^{2}$ Key Laboratory of Plant Nutrition and the Agric-environment in Northwest China, Ministry \\ of Agriculture, Yangling, Shannxi 712100,China*Corresponding author: zhangshulan@nwsuaf.edu.cn
}

\begin{abstract}
A long-term field experiment was conducted over a twenty year period to examine the effects of three different soil management regimes (Abandonment, Fallow and Cropping) and eight nutrient management regimes under Cropping on soil organic carbon (SOC), $\mathrm{N}$ and $\mathrm{P}$ levels, microbial biomass, and enzymatic activities related to $\mathrm{C}, \mathrm{N}$, and $\mathrm{P}$ cycling in a loess soil. The nutrient management regimes examined involved treatment with various combinations of inorganic nitrogen, phosphorus, and potassium fertilizers (N, NP, PK, and NPK), as well as combinations of NPK fertilizers with either residual plant material (SNPK) or manure (MN1PK and MN2PK). Abandonment resulted in greater levels of soil microbial biomass than did Cropping but similar levels of enzyme activity were observed under both regimes. The Fallow regime gave significantly lower soil organic carbon levels and enzyme activities than did Cropping. Within the Cropping system, the treatments containning nitrogen and phophorus significantly improved SOC, N and P levels and also increased microbial biomass and enzyme activity relative to the control. In general, the highest values of the tested soil parameters were observed under the M2NPK treatment. With the exception of invertase, the activity of all soil enzymes tested correlated significantly with SOC and microbial biomass. It was concluded that the use of fertilization regimes involving applying organic material in conjunction with NPK fertilizers should be encouraged in order to maintain or improve the chemical and biological properties of the tested loess soil and to thereby increase its productivity.
\end{abstract}

Keywords: Long-term experiment, soil organic carbon, microbial biomass, soil enzymes

\section{Introduction}

The chemical and biochemical properties of soils have profound impacts on their quality and are highly sensitive to soil and crop management practices. Soil microorganisms are responsible for innumerable processes that occur in soils, and the soil microbial biomass is more sensitive than total organic carbon or nitrogen to changes in soil quality (Bolinder et al., 1999). Soil enzymes, mainly produced by microorganisms, are the mediators and catalysts of biochemical processes that are important in soil 
functioning, such as nutrient mineralization and cycling, the decomposition and formation of soil organic matter, and the decomposition of xenobiotics (i.e. pesticides) (Acosta-Martinez et al., 2007). A number of studies have shown that soil microbial biomass and enzyme activity can be adjusted by making suitable changes to the applied soil and crop management regimes. Such changes might affect the application of organic manure and inorganic fertilizers (Adriano et al., 2012; Tamilseli et al., 2015), the cropping system used (Böhme and Böhme, 2006), tillage (Zhang et al., 2010), or the use to which the land is put (Mganga et al., 2015). Moreover, Caravaca et al. (2002) reported that in a semiarid Mediterranean environment, dehydrogenase, urease and phosphatase activities were more sensitive and responded more frequently to land use than did the soil's total organic carbon, water soluble carbon, or water-soluble carbohydrate contents. It has been suggested that soil enzyme activity, which accounts for the bulk of all soil microbial activity, may be more useful for comparing stresses across different soils and vegetation types than either total organic carbon or microbial biomass carbon (Caldwell et al., 1999). Thus, data on enzyme activity can be used to monitor and describe changes in soil quality due to changes in land use or soil management practices and to understand soil ecosystem functioning.

Long-term experiments are useful for monitoring changes in soil quality induced by the adoption of new cropping systems, soil management practices, fertilizer usage patterns, or approaches to residue management, etc. It has been shown that the nature of the applied soil management regime can strongly affect soil chemical and biochemical properties, but also that such effects depend (inter alia) on the regional climate, soil type, and the intensity of management (Böhme and Böhme, 2006). However, few studies have compared the effects of cropland abandonment and the use of specific cropping systems on soil microbial biomass and enzyme activities (Caldwell et al., 1999; Liu et al., 2008), although both approaches could potentially facilitate attempts to restore soil quality in targeted areas. A series of long-term experiments was initiated in China during the 1980s and early 1990s with the aim of monitoring the effects of different soil management regimes on soil fertility, crop productivity and fertilizer use efficiency. A variety of regimes based on both organic and inorganic nutrient sources were examined; one of them was similar to that typically used by local farmers. These experiments provided a rich body of data with which to evaluate the impact of soil management on soil quality parameters. We hypothesized that the soil's chemical and biological properties would be dependent on the nature of the applied soil- and nutrient-management regime, which would consequently affect the productivity of the system. It was thus expected that it would be possible to optimize these soil parameters by abandoning cropland over a long period of time or subjecting it to balanced or imbalanced fertilization with or without the addition of organic material. In the study presented here, we evaluated these hypotheses using cropland plots on a loess soil that had been abandoned, left fallow, or subjected to an intensive wheat-maize cropping system with various nutrient regimes, for 20 years.

\section{Materials and Methods}

\subsection{Study site and experimental design}

A long-term experiment was established in October 1990 at the Chinese National Soil Fertility and Fertilizer Efficiency Monitoring Base of Loessial Soil (N 34 ${ }^{\circ}$ $17^{\prime} 51^{\prime}$, E $108^{\circ} 00^{\prime} 48^{\prime \prime}$, at an altitude of 524.7 meters a.s.l.). The Base is located on levelled land on the third terrace of the Weihe River, a tributary of the Yellow River, Yangling, Shaanxi, China. According to the USDA texture classification system, the soil at the site is a silt clay loam (Eumorthic Anthrosols, FAO) derived from loess materials. On average, at the time of establishment 
the soil at the site contained $7.44 \mathrm{~g} \mathrm{~kg}^{-1}$ organic $\mathrm{C}$, $0.93 \mathrm{~g} \mathrm{~kg}^{-1}$ total $\mathrm{N}, 9.57 \mathrm{mg} \mathrm{kg}^{-1}$ Olsen $\mathrm{P}, 191 \mathrm{mg} \mathrm{kg}^{-1}$ exchangeable $\mathrm{K}, 92.5 \mathrm{~g} \mathrm{~kg}^{-1} \mathrm{CaCO}_{3}$ and had $\mathrm{pH}$ of 8.62 across all plots, with low variability (C.V.' $6 \%$, except for Olsen-P, $15 \%$ ). The experimental site has a mean annual temperature of $13.0^{\circ} \mathrm{C}$, and mean annual precipitation of ca. $550 \mathrm{~mm}$, which mainly falls from June to September. The field experiment was previsously described in detail by Yang et al. (2012). Three different soil management regimes were examined here. In the first, the plots were left fallow; no vegetation was grown, no fertilizer or manure was applied, and weeds were manually controlled (hoed) and plowed in on an annual basis during October; this regime is henceforth referred to as Fallow. In the second, the plots were abandoned, without any artificial perturbation; plants were allowed to grow naturally, and so numerous species of herbaceous and a few arboreous plants thrived. This regime is henceforth referred to as Abandonment. In the third, a winter wheat (Triticum aestivum L.)-summer maize (Zea mays L.) rotation system was used, with two crops per year; this regime is henceforth referred to as Cropping. The Cropping regime was tested with eight different nutrient management treatments: no added fertilizer or manure (the control treatment, henceforth referred to as $\mathrm{CK}$ ); various combinations of inorganic $\mathrm{N}$, $\mathrm{P}$, and $\mathrm{K}$ fertilizers alone (specifically, N, NP, PK, and NPK), NPK with wheat straw or maize stalk (SNPK), and two regimes using NPK with dairy manure. The two 'NPK plus manure' regimes were designated M1NPK and M2NPK; the M refers to dairy manure and the subsequent number indicates the quantity of manure applied (see Table 1 for details).

Table 1. Details of the fertilizer treatments and quantities of fertilizer applied $\left(\mathrm{kg} \mathrm{ha}^{-1}\right)$

\begin{tabular}{lcccccc}
\hline \multirow{2}{*}{ Treatments } & \multicolumn{3}{c}{ winter wheat } & \multicolumn{3}{c}{ summer maize } \\
\cline { 2 - 7 } & $\mathrm{N}$ & $\mathrm{P}$ & $\mathrm{K}$ & $\mathrm{N}$ & $\mathrm{P}$ & $\mathrm{K}$ \\
\hline $\mathrm{CK}$ & 0 & 0 & 0 & 0 & 0 & 0 \\
$\mathrm{~N}$ & 165.0 & 0 & 0 & 187.5 & 0 & 0 \\
PK & 0 & 57.6 & 68.5 & 0 & 24.6 & 77.8 \\
NP & 165.0 & 57.6 & 0 & 187.5 & 24.6 & 0 \\
NPK & 165.0 & 57.6 & 68.5 & 187.5 & 24.6 & 77.8 \\
SNPK & 165.0 & 57.6 & 68.5 & 187.5 & 24.6 & 77.8 \\
M1NPK & 165.0 & 57.6 & 68.5 & 187.5 & 24.6 & 77.8 \\
M2NPK & 247.5 & 86.4 & 102.8 & 187.5 & 24.6 & 77.8 \\
\hline
\end{tabular}


Overall, the study examined the effects of two different types of management regime and a total of ten treatments, one of which (NP) was similar to that typically used by local farmers. Between 1990 and 1998, the SNPK plot was treated with $4500 \mathrm{~kg}$ (airdried) of wheat straw ha ${ }^{-1}$; from 1999 until the end of the experiment, it was instead treated with the aboveground maize stalk collected from the plot, which had a mean annual mass of $4392 \mathrm{~kg} \mathrm{ha}^{-1}$ (ranging from 2630 to $\left.5990 \mathrm{~kg} \mathrm{ha}^{-1}\right)$. The added straw/stalk was manually chopped into pieces approximately $3 \mathrm{~cm}$ in length and incorporated into the soil during the autumn before the sowing of the winter wheat. Dairy manure and straw were also added once per year, before the sowing of the wheat. The M1NPK plot was given the same quantities of P and $\mathrm{K}$ as the NPK plot but received only $30 \%$ as much $\mathrm{N}$ from inorganic fertilizers; the remainder was supplied in the form of organic manure. In the M2NPK treatment, the amounts of manure and inorganic $\mathrm{N}, \mathrm{P}$, and $\mathrm{K}$ applied during the winter wheat season were $50 \%$ greater than those applied in the M1NPK treatment. In the summer maize season, the M1NPK and M2NPK plots received the same quantities of $\mathrm{N}, \mathrm{P}$ and $\mathrm{K}$ from inorganic fertilizers as were applied in the NPK treatment, and no organic manure was added. The $\mathrm{C}$ and $\mathrm{N}$ contents of the manure were about $26.45 \% \pm 7.82$ (SD) and 1.32 $\% \pm 0.91$ (SD) by mass, respectively. The annual mean dry weight of organic manure applied was $13.7 \mathrm{t} \pm 7.2$ and $20.6 \mathrm{t} \pm 10.8$ (SD) in the M1NPK and M2NPK treatments, respectively, over the experimental years. The mean annual inputs of N, P and K contributed by wheat straw or maize stalk were $40.1,3.6$ and $83.5 \mathrm{~kg}$ ha $^{-1}$, respectively. For the M1NPK plot, the amounts of $\mathrm{P}$ and $\mathrm{K}$ supplied by dairy manure were 130.0 and $200.0 \mathrm{~kg} \mathrm{ha}^{-1}$, respectively; for the M2NPK plot, the corresponding amounts were 210.0 and $315.0 \mathrm{~kg}$ ha${ }^{1}$, respectively. Neither the N, P and $\mathrm{K}$ originating from straw/stalk nor the $\mathrm{P}$ and $\mathrm{K}$ from dairy manure are accounted for in the figures shown in Table 1. All inorganic fertilizers and organic materials applied were incorporated into the soil to plowing depth (ca. $20 \mathrm{~cm}$ ) before the winter wheat was sown and about one month after the planting of the maize. $\mathrm{N}$ was applied as urea, $\mathrm{P}$ as single super-phosphate, and $\mathrm{K}$ as potassium sulfate. Winter wheat was sown in October and harvested in the following June; summer maize was planted and harvested about three months later, at the end of September or early in October. The plots were irrigated with ground water once or twice during the winter wheat season and between two and four times annually during the summer maize season, as required; approximately $90 \mathrm{~mm}$ of water was applied on each occasion. All above-ground crop residues were removed after harvest unless otherwise specified. The fields were conventionally tilled.

\subsection{Soil sampling and analyses}

Soil samples $(0-20 \mathrm{~cm})$ were taken at the end of May 2010 , one week before harvesting the winter wheat. For each treatment, 30 soil cores with a diameter of 2.5 $\mathrm{cm}$ were taken randomly and combined in sets of 10 to form three composite samples for each treatment. After carefully removing the surface organic materials and fine roots, each mixed soil sample was divided into two portions. One portion was air-dried for the estimation of soil chemical properties and enzymatic activity, and the other was passed through a $2 \mathrm{~mm}$ screen and stored at $4{ }^{\circ} \mathrm{C}$ in a plastic bag for microbial biomass analysis.

Soil $\mathrm{pH}$ was measured using a glass electrode in a 1:2.5 (w/w) suspension of air-dried soil in $\mathrm{CO}_{2}{ }^{-}$ free distilled water. Soil organic carbon (SOC) was determined by potassium bichromate oxidationferrous sulfate titration (Niu, 1983). Soil total N (TN) was assayed using the semi-micro Kjeldahl method after $\mathrm{H}_{2} \mathrm{SO}_{4}$ digestion in the presence of a $\mathrm{K}_{2} \mathrm{SO}_{4}$ - 
$\mathrm{CuSO}_{4}$-Se catalyst (Bremner, 1996). Total phosphorus (TP) was digested with $\mathrm{HNO}_{3}-\mathrm{HF}-\mathrm{HClO}_{3}$ (Emteryd, 2002). The soil available phosphorus (AP, here defined in terms of Olsen $\mathrm{P}$ ) in the samples was extracted with $0.5 \mathrm{M} \mathrm{NaHCO}_{3}(\mathrm{pH}$ 8.5). Phosphorus concentrations in the digests and extracts were determined by the procedure of Murphy and Riley (1962). Microbial biomass carbon (MBC) and microbial biomass nitrogen $(\mathrm{MBN})$ were estimated by comparing the levels of organic $\mathrm{C}$ and inorganic $\mathrm{N}$ in the potassium sulfate $\left(\mathrm{K}_{2} \mathrm{SO}_{4}\right)$ extracts of fumigated soils to those in unfumigated soil, as described by Wu et al. (1990). The MBC and MBN were calculated using a Phoenix 8000 organic C analyzer (Teledyne-Tekmar, Mason $\mathrm{OH})$ for $\mathrm{C}$ determination and a flow injection analyzer for $\mathrm{N}$ determination; it was assumed that $\mathrm{KEC}=0.45$ and $\mathrm{KEN}=0.54$. Soil dehydrogenase activity, alkali phosphatase enzyme activities, invertase activity, and urease activity were measured using the methods of Guan (1986).

One-way analysis of variance was then used to analyze between-treatment differences in the tested parameters. The least significant difference method (LSD) at the $5 \%$ probability level was used to test the significance of differences between treatment means. All statistical analyses were performed using SPSS 12.0.1 for Windows.

\section{Results}

\subsection{Soil chemical properties}

\subsubsection{The effects of soil management}

The nature of the soil management regime applied over the 20 year experimental period was found to significantly influence the soil chemical properties (Table 2). Local farmers in the region where the experiment was conducted typically use NP fertilizers without manure or a $\mathrm{K}$ fertilizer in a winter wheatsummer maize rotation system. Much of the following discussion therefore focuses on comparing the effects of the Fallow, Abandonment and NP (Cropping) regimes. The soil $\mathrm{pH}$ under Cropping was similar to that under Fallow and significantly lower than that under Abandonment. SOC and TN levels were significantly lower under Fallow than under Abandonment or Cropping, both of which exhibited similar SOC and TN levels (Table 2). In contrast to the effects on SOC and TN, the $\mathrm{C} / \mathrm{N}$ ratio did not differ greatly between the three soil management regimes. The TP and AP levels were substantially lower under Fallow and Abandonment than under Cropping.

3.1.2. The effects of nutrient management under cropping

The cropping treatments that incorporated the application of inorganic fertilizers with or without organic materials (i.e. maize stalks or manure) exhibited significantly lower soil $\mathrm{pH}$ values than did the control (8.51) (Table 2). The SOC levels for the $\mathrm{CK}, \mathrm{N}$, and PK treatments were all similar and significantly lower than those for the other treatments; the highest SOC levels were achieved with the MNPK treatments. However, the application of wheat or maize straw/stalk in conjunction with NPK fertilizers had no discernible effect on SOC levels relative to those observed with NPK alone. The effects of the different fertilizer treatments on TN levels were similar to those observed for SOC, although the TN content was markedly higher under $\mathrm{N}$ than under CK. All treatments gave rise to similar $\mathrm{C} / \mathrm{N}$ ratios with the exception of MNPK, for which the $\mathrm{C} / \mathrm{N}$ ratio was significantly lower than in the others. The TP and AP concentrations ranged from 0.65 to 1.93 $\mathrm{g} \mathrm{kg}^{-1}$ and 3.5 to $377.2 \mathrm{mg} \mathrm{kg}^{-1}$, respectively. The MNPK treatment gave substantially higher TP and AP 
concentrations than did the control; the lowest TP and AP concentrations were associated with treatments that had no added $\mathrm{P}(\mathrm{CK}$ and $\mathrm{N})$. The PK treatment, which did not involve the addition of an N-containing fertilizer, gave significantly higher soil TP levels than did the NP, NPK, or SNPK treatments.

Table 2. Soil chemical properties and microbial biomass in a long-term loess soil management experiment (1990-2010)

\begin{tabular}{|c|c|c|c|c|c|c|c|c|c|c|c|}
\hline \multirow{2}{*}{ System } & \multirow{2}{*}{ Treatment } & $\mathrm{pH}$ & SOC & $\mathrm{TN}$ & TP & Olsen P & $\mathrm{SOC} / \mathrm{TN}$ & $\mathrm{MBC}$ & MBN & $\mathrm{MBC} / \mathrm{MBN}$ & $\mathrm{MBC} / \mathrm{SOC}$ \\
\hline & & $(1: 2.5)$ & $\mathrm{g} \mathrm{kg}^{-1}$ & $\mathrm{~g} \mathrm{~kg}^{-1}$ & $\mathrm{~g} \mathrm{~kg}^{-1}$ & $\mathrm{mg} \mathrm{kg}^{-1}$ & $\mathrm{~g} \mathrm{C} \mathrm{g} \mathrm{N}^{-1}$ & $\mathrm{mg} \mathrm{kg}^{-1}$ & $\mathrm{mg} \mathrm{kg}^{-1}$ & $\mathrm{mg} \mathrm{C} \mathrm{mg} \mathrm{N}^{-1}$ & $\mathrm{mg} \mathrm{C} \mathrm{g} \mathrm{C}^{-1}$ \\
\hline \multirow{3}{*}{$\begin{array}{c}\text { Soil } \\
\text { management } \\
\text { regimes }\end{array}$} & Fallow & $8.33 \mathrm{~b}$ & $7.89 \mathrm{~b}$ & $0.97 \mathrm{~b}$ & $0.63 \mathrm{~b}$ & $3.2 \mathrm{~b}$ & $8.1 \mathrm{a}$ & $191.1 \mathrm{~b}$ & $35.2 \mathrm{~b}$ & $5.5 \mathrm{a}$ & $24.2 \mathrm{~b}$ \\
\hline & Abandonment & $8.46 \mathrm{a}$ & $10.75 \mathrm{a}$ & $1.25 \mathrm{a}$ & $0.61 \mathrm{~b}$ & $4.2 \mathrm{~b}$ & $8.6 \mathrm{a}$ & $344.7 \mathrm{a}$ & $68.2 \mathrm{a}$ & $5.3 \mathrm{a}$ & $32.1 \mathrm{a}$ \\
\hline & NP & $8.28 \mathrm{~b}$ & $10.16 \mathrm{a}$ & $1.26 \mathrm{a}$ & $1.03 \mathrm{a}$ & $43.5 \mathrm{a}$ & $8.0 \mathrm{a}$ & $211.1 \mathrm{~b}$ & $47.9 \mathrm{~b}$ & $4.4 \mathrm{a}$ & $20.8 \mathrm{~b}$ \\
\hline \multirow{8}{*}{$\begin{array}{l}\text { Winter wheat- } \\
\text { summer } \\
\text { maize rotation } \\
\text { system }\end{array}$} & CK & $8.51 \mathrm{a}$ & $7.58 \mathrm{~d}$ & $0.94 \mathrm{~g}$ & $0.65 \mathrm{e}$ & $3.5 \mathrm{e}$ & $8.1 \mathrm{a}$ & $161.0 \mathrm{de}$ & $31.1 \mathrm{ef}$ & 5.3 abcd & $21.2 \mathrm{de}$ \\
\hline & $\mathrm{N}$ & $8.35 \mathrm{~cd}$ & $8.51 \mathrm{~d}$ & $1.09 \mathrm{ef}$ & $0.67 \mathrm{e}$ & $3.6 \mathrm{e}$ & $7.8 \mathrm{ab}$ & $144.0 \mathrm{e}$ & $24.3 \mathrm{f}$ & $5.9 \mathrm{ab}$ & $16.9 \mathrm{e}$ \\
\hline & NP & $8.28 \mathrm{~d}$ & $10.16 \mathrm{c}$ & $1.26 \mathrm{~cd}$ & $1.03 \mathrm{~d}$ & $43.5 \mathrm{~cd}$ & $8.0 \mathrm{ab}$ & $211.1 \mathrm{~cd}$ & $47.9 \mathrm{de}$ & $4.4 \mathrm{bcd}$ & $20.8 \mathrm{de}$ \\
\hline & PK & $8.38 \mathrm{bc}$ & $8.37 \mathrm{~d}$ & $1.07 \mathrm{fg}$ & $1.20 \mathrm{c}$ & $60.1 \mathrm{c}$ & $7.8 \mathrm{ab}$ & $185.6 \mathrm{de}$ & $51.4 \mathrm{~cd}$ & $3.7 \mathrm{~d}$ & $22.3 \mathrm{cde}$ \\
\hline & NPK & $8.28 \mathrm{~d}$ & $10.03 \mathrm{c}$ & $1.22 \mathrm{de}$ & $0.97 \mathrm{~d}$ & $32.5 \mathrm{~d}$ & $8.2 \mathrm{a}$ & $247.3 \mathrm{c}$ & $49.9 \mathrm{~d}$ & $5.1 \mathrm{abcd}$ & $24.6 \mathrm{bcd}$ \\
\hline & SNPK & $8.34 \mathrm{~cd}$ & $10.98 \mathrm{c}$ & $1.39 \mathrm{c}$ & $1.04 \mathrm{~d}$ & $50.8 \mathrm{c}$ & $7.9 \mathrm{ab}$ & $320.2 \mathrm{~b}$ & $50.9 \mathrm{~d}$ & $6.5 \mathrm{a}$ & $29.1 \mathrm{abc}$ \\
\hline & M1NPK & $8.28 \mathrm{~d}$ & $12.63 \mathrm{~b}$ & $1.79 \mathrm{~b}$ & $1.62 \mathrm{~b}$ & 242.8 b & $7.1 \mathrm{~b}$ & $445.0 \mathrm{a}$ & $99.7 \mathrm{~b}$ & $4.5 \mathrm{bcd}$ & $31.6 \mathrm{ab}$ \\
\hline & M2NPK & $8.28 \mathrm{~d}$ & $13.88 \mathrm{a}$ & $1.90 \mathrm{a}$ & $1.93 \mathrm{a}$ & $377.2 \mathrm{a}$ & $7.3 \mathrm{~b}$ & $488.1 \mathrm{a}$ & $120.4 \mathrm{a}$ & $4.1 \mathrm{~cd}$ & $35.6 \mathrm{a}$ \\
\hline
\end{tabular}

Note: In each column, numbers that are followed by different letters differed significantly between treatments at $P<0.05$.

SOC refers to total Soil Organic Carbon; TN to Total soil Nitrogen; TP to Total soil Phosphorus; MBC to Microbial Biomass Carbon; and MBN to Microbial Biomass Nitrogen

\subsection{Soil microbial biomass $C$ and $N$}

\subsubsection{The effects of soil management}

The MBC and MBN levels for Fallow and Cropping were indistinguishable and markedly lower than those under Abandonment (Table 2). Like the $\mathrm{C} / \mathrm{N}$ ratio, the $\mathrm{MBC} / \mathrm{MBN}$ ratio was relatively insensitive to the nature of the applied soil management regime. The MBC to SOC ratio was significantly higher under Abandonment (32.1 $\mathrm{mg} \mathrm{g}^{-1}$ ) than under Cropping (20.8 $\mathrm{mg} \mathrm{g}^{-1}$ ) or Fallow $\left(24.2 \mathrm{mg} \mathrm{g}^{-1}\right.$ ) but did not differ significantly between the latter two treatments.
3.2.2. Effect of nutrient management under cropping

The highest soil MBC levels were observed under the treatments in which manure was applied in conjunction with NPK (445 -488 $\mathrm{mg} \mathrm{kg}^{-1}$ ), followed by SNPK (320 mg kg-1) and then by NPK and NP (247 and $199 \mathrm{mg} \mathrm{kg}^{-1}$, respectively); see Table 2. The $\mathrm{CK}, \mathrm{N}$ and PK treatments exhibited the lowest MBC levels, ranging from 144 to $191 \mathrm{mg} \mathrm{kg}^{-1}$. The $\mathrm{CK}$ and $\mathrm{N}$ treatments gave low MBN levels; substantially higher values were observed under PK, NPK and SNPK, while the highest MBN values were observed in the MNPK plots. In contrast, the $\mathrm{MBC} / \mathrm{MBN}$ ratio 
was highest under SNPK and lowest under the PK treatment. The MBC to SOC ratios ranged from 16.9 $\mathrm{mg} \mathrm{g}^{-1}$ to $35.6 \mathrm{mg} \mathrm{g}^{-1}$, with the highest value being observed under M2NPK and the lowest under N.

\subsection{Soil enzymatic activity}

\subsubsection{The effects of soil management}

The applied soil management practices had profound effects on the measured enzyme activities
(Table 3). The activities of dehydrogenase and alkaline phosphatase under the Abandonment and Cropping treatments were comparable and were both significantly higher than those observed under Fallow. Conversely, Abandonment and Fallow exhibited similar levels of invertase activity, with both being lower than that observed under Cropping. The urease activity under Abandonment did not differ significantly from those observed under Cropping or Fallow, but that under Cropping was significantly higher than that under Fallow.

Table 3. Soil enzymatic activity in a long-term loess soil management experiment (1990-2010)

\begin{tabular}{|c|c|c|c|c|c|}
\hline System & Treatment & $\begin{array}{c}\text { Dehydrogenase } \\
\left(\mathrm{mg} \mathrm{TPF}^{-1} 24\right. \\
\left.\mathrm{h}^{-1}\right)\end{array}$ & $\begin{array}{c}\text { Invertase } \\
(\mathrm{mg} \text { glucose } \\
\left.\mathrm{g}^{-1} 24 \mathrm{~h}^{-1}\right)\end{array}$ & $\begin{array}{c}\text { Urease } \\
\left(\mathrm{mg} \mathrm{NH}_{4}^{+}-\mathrm{N}\right. \\
\left.\mathrm{g}^{-1} 24 \mathrm{~h}^{-1}\right)\end{array}$ & $\begin{array}{c}\text { Alkaline } \\
\text { phosphatase } \\
\left(\mathrm{mg} \mathrm{PNP} \mathrm{g}^{-1}\right. \\
\left.24 \mathrm{~h}^{-1}\right)\end{array}$ \\
\hline Soil & Fallow & $0.196 \mathrm{~b}$ & $1.98 \mathrm{~b}$ & $0.803 \mathrm{c}$ & $1.877 \mathrm{~b}$ \\
\hline management & Abandment & $0.285 \mathrm{a}$ & $5.77 \mathrm{~b}$ & $0.984 \mathrm{bc}$ & $2.781 \mathrm{a}$ \\
\hline \multirow[t]{3}{*}{ regimes } & NP & $0.310 \mathrm{a}$ & $19.22 \mathrm{a}$ & $1.069 \mathrm{ab}$ & $2.778 \mathrm{a}$ \\
\hline & CK & $0.225 \mathrm{e}$ & $12.49 \mathrm{c}$ & $0.462 \mathrm{c}$ & $2.146 \mathrm{~d}$ \\
\hline & $\mathrm{N}$ & $0.224 \mathrm{e}$ & $12.65 \mathrm{c}$ & $0.946 \mathrm{~b}$ & $2.328 \mathrm{~cd}$ \\
\hline Winter wheat- & NP & $0.310 \mathrm{~cd}$ & $19.22 \mathrm{ab}$ & $1.069 \mathrm{ab}$ & $2.778 \mathrm{~b}$ \\
\hline summer maize & PK & $0.271 \mathrm{cde}$ & $14.83 \mathrm{bc}$ & $0.633 \mathrm{c}$ & $2.204 \mathrm{~cd}$ \\
\hline rotation & NPK & $0.265 \mathrm{de}$ & $18.89 \mathrm{ab}$ & $0.957 \mathrm{~b}$ & $2.478 \mathrm{c}$ \\
\hline \multirow[t]{3}{*}{ system } & SNPK & $0.325 \mathrm{c}$ & $21.49 \mathrm{a}$ & $0.894 \mathrm{~b}$ & $3.049 \mathrm{~b}$ \\
\hline & M1NPK & $0.470 \mathrm{~b}$ & $19.38 \mathrm{ab}$ & $1.254 \mathrm{a}$ & $3.037 \mathrm{~b}$ \\
\hline & M2NPK & $0.536 \mathrm{a}$ & $20.64 \mathrm{ab}$ & $1.087 \mathrm{ab}$ & $3.667 \mathrm{a}$ \\
\hline
\end{tabular}

Note: In each column, numbers that are followed by different letters differed significantly between treatments at $\mathrm{P}<0.05$. 
3.3.2. The effects of nutrient management under cropping

In general, the highest enzyme activities were observed under the M2NPK treatment, while the lowest were observed under CK, N, and PK (Table 3 ). Thus, the dehydrogenase activity of the soil samples decreased in the following order (based on statistical significance): M2NPK > M1NPK $>$ SNPK $>$ NPK, NP, PK $>$ CK and N. The measured invertase activities ranged from $12.49 \mathrm{mg}$ glucose $\mathrm{g}^{-1} 24 \mathrm{~h}^{-1}$ for CK to $20.64 \mathrm{mg}$ glucose $\mathrm{g}^{-1} 24 \mathrm{~h}^{-1}$ for M2NPK. There was no significant difference between the invertase activities measured for the MNPK, SNPK, NPK and NP treatments, or between those measured for PK, N, and CK. The soils' urease activity values ranged from 0.462 mg NH${ }_{4}^{+}-\mathrm{N} \mathrm{g}^{-1} 24 \mathrm{~h}^{-1}$ to $1.254 \mathrm{mg} \mathrm{NH}_{4}^{+}-\mathrm{N} \mathrm{g}^{-1} 24 \mathrm{~h}$ ${ }^{1}$; the lowest were observed for the treatments without added $\mathrm{N}$ (i.e. CK and PK) and the highest in M1NPK. Alkaline phosphatase activity was highest under M2NPK, followed by M1NPK, SNPK and NP, and then by NPK; it was lowest under $\mathrm{CK}, \mathrm{N}$ and $\mathrm{PK}$.

\subsection{Grain yield}

The mean grain yield for the wheat grown on the cropping plots during the 20 -year experiment was significantly higher under the M2NPK treatment than the NP, PK, NK, N and CK treatments, and nonsignificantly higher than the yields obtained under the M1NPK, SNPK and NPK treatments (Table 4). The yield obtained under the NP treatment was similar to those for the M1NPK, SNPK and NPK treatments but significantly higher than those for the PK, NK, $\mathrm{N}$ and $\mathrm{CK}$ treatments, all of which were similar. There was no significant difference between the three treatments involving the application of organic fertilizer (i.e. SNPK and the two MNPK treatments). However, the yields under the MNPK treatments were significantly higher than those obtained using chemical fertilization alone, whereas that for the SNPK treatment did not differ significantly from those for the NPK or NP treatments (Table 4). In addition, the NPK and NP treatments gave significantly higher maize grain yields than the PK, NK, N and CK treatments. In sharp contrast to wheat, the maize grain yield was detectably higher under the NK treatment than under the $\mathrm{N}$ treatment and substantially greater under $\mathrm{N}$ than under $\mathrm{PK}$ or $\mathrm{CK}$. The total yield (wheat plus maize) was significantly higher under M2NPK than under the treatments using chemical fertilizer alone or NPK combined with straw. The M1NPK, SNPK, NPK and NP treatments all gave similar total yields, all of which were higher than those obtained under the PK, NK, N and CK treatments.

\subsection{Correlations}

Correlation studies revealed the existence of significant relationships between certain soil properties (Table 5). There was no strong correlation between the soil $\mathrm{pH}$ and $\mathrm{MBC}, \mathrm{MBN}$, or any measured enzyme activity with the exception of urease activity, which exhibited a significant positive correlation with soil $\mathrm{pH}$. MBC, MBN and the measured enzyme activities generally exhibited strong positive correlations $(p<0.01)$ with SOC and the concentrations of soil nutrients. The two exceptions in this respect were invertase 
activity, which did not correlate significantly with the SOC, TN, or AP concentrations, and urease activity, which did not correlate significantly with TP and AP levels. Of the measured soil biochemical properties, dehydrogenase, urease and alkaline phosphatase activities all exhibited significant positive correlations with soil MBC. Dehydrogenase and alkaline phosphatase activities were significantly and positively correlated with soil MBN. Dehydrogenase was the enzyme whose activity was most strongly correlated with $\mathrm{MBC}$ and $\mathrm{MBN}$. A significant and positive correlation was also observed between the activities of alkaline phosphatase, dehydrogenase, and urease. However, invertase activity did not correlate strongly with that of any enzyme other than alkaline phosphatase.

Table 4. Mean grain yields in a long-term (1991-2010) experiment conducted in Yangling, Shaanxi, China

\begin{tabular}{|c|c|c|c|}
\hline \multirow{2}{*}{ Treatment } & Winter wheat & Summer maize & Wheat + maize \\
\hline & \multicolumn{3}{|c|}{$\mathrm{kg} \mathrm{ha}^{-1}$} \\
\hline $\mathrm{CK}$ & $992 \mathrm{c}$ & $2235 \mathrm{f}$ & $3228 \mathrm{e}$ \\
\hline $\mathrm{N}$ & $1030 \mathrm{c}$ & $3002 \mathrm{e}$ & $4032 \mathrm{~cd}$ \\
\hline NK & $1269 \mathrm{c}$ & $3447 \mathrm{~d}$ & $4716 \mathrm{c}$ \\
\hline PK & $1247 \mathrm{c}$ & $2544 \mathrm{f}$ & 3792 de \\
\hline NP & $5329 \mathrm{~b}$ & $6286 \mathrm{bc}$ & $11615 \mathrm{~b}$ \\
\hline NPK & $5476 \mathrm{ab}$ & $6144 \mathrm{c}$ & $11620 \mathrm{~b}$ \\
\hline SNPK & $5573 \mathrm{ab}$ & $6512 \mathrm{abc}$ & $12085 \mathrm{~b}$ \\
\hline M1NPK & $5668 \mathrm{ab}$ & $6644 \mathrm{ab}$ & $12312 \mathrm{ab}$ \\
\hline M2NPK & $5962 \mathrm{a}$ & $6894 \mathrm{a}$ & $12855 \mathrm{a}$ \\
\hline
\end{tabular}

Note: In each column, numbers that are followed by different letters differed significantly between treatments at $\mathrm{P}<0.05$. 
Table 5. Linear correlation coefficients between soil chemical properties, microbial biomass and enzyme activities for ten treatments in a long-term loess soil management experiment (1990-2010)

\begin{tabular}{|c|c|c|c|c|c|c|c|c|c|c|}
\hline & SOC & $\mathrm{TN}$ & TP & AP & MBC & MBN & $\mathrm{DE}$ & Ure & AKP & Inv \\
\hline $\mathrm{pH}$ & -0.53 & -0.55 & -0.60 & -0.50 & -0.36 & -0.40 & -0.49 & $-0.72 *$ & -0.42 & -0.52 \\
\hline SOC & & $0.97 * *$ & $0.82 * *$ & $0.86^{* *}$ & $0.95 * *$ & $0.92 * *$ & $0.94 * *$ & $0.81 * *$ & $0.9^{* *}$ & 0.59 \\
\hline $\mathrm{TN}$ & & & $0.89 * *$ & $0.95^{* *}$ & $0.93 * *$ & $0.94 * *$ & $0.98 * *$ & $0.74 *$ & $0.93 * *$ & 0.6 \\
\hline TP & & & & $0.95 * *$ & $0.76^{*}$ & $0.87 * *$ & $0.93 * *$ & 0.52 & $0.76^{* *}$ & $0.69^{*}$ \\
\hline AP & & & & & $0.86^{* *}$ & $0.92 * *$ & $0.97 * *$ & 0.54 & $0.82 * *$ & 0.57 \\
\hline MBC & & & & & & $0.95^{* *}$ & $0.91 * *$ & $0.67 *$ & $0.87 * *$ & 0.4 \\
\hline MBN & & & & & & & $0.95 * *$ & 0.62 & $0.84 * *$ & 0.42 \\
\hline DE & & & & & & & & $0.66^{*}$ & $0.91 * *$ & 0.62 \\
\hline Ure & & & & & & & & & $0.68^{*}$ & 0.29 \\
\hline AKP & & & & & & & & & & $0.66^{*}$ \\
\hline
\end{tabular}

Note: * and ** indicate $P<0.05$ and $P<0.01$, respectively. $\mathrm{SOC}=$ Total soil organic carbon; $\mathrm{TN}=$ total soil nitrogen; $\mathrm{AP}=$ available phosphorous (Olsen $\mathrm{P}) ; \mathrm{MBC}=$ Microbial biomass carbon; $\mathrm{MBN}=$ Microbial biomass nitrogen; $\mathrm{DE}=\mathrm{Dehydrogenase}$; Inv $=$ Invertase $;$ Ure $=$ Urease $; \mathrm{AkP}=$ Alkaline Phosphatase $)$.

\section{Discussion}

\subsection{Soil management regimes}

The nature of the applied soil management regime influences the soil biochemical properties because it affects the soil's nutrient inputs and the quantity and quality of plant residues entering the soil (Burns, 1978). Under the Fallow regime, the soil received no inputs with the exception of some weeds that had taken root there prior to hoeing. Consequently, it exhibited the lowest concentrations of SOC, N and P (Table 2) of all the regimes considered; this depressed enzyme activity substantially (Table 3 ). These findings are consistent with those of a previous study, in which it was found that compared to a control system, bare soil with no inputs exhibited reduced SOC and depressed enzymatic activity (Caldwell et al., 1999). However, we found that the soil microbial biomass (MBC and MBN) under the Fallow regime was similar to that under Cropping, which is inconsistent with the findings of previous studies (Caldwell et al., 1999; Witter and Kanal, 1998). It is possible that this apparent contradiction stems from differences in soil moisture. The production of the high yields obtained under Cropping (Table 4) would be expected to deplete the soil moisture much more extensively than would be the case under the Fallow regime, meaning that the soil microbes in the Cropping plots would have been under relatively high stress during sampling (which was conducted at wheat maturity). In all fertilized plots in the experiment, it was observed that the MBC was substantially lower during the winter wheat maturation period than during the jointing and 
flowering stages (unpublished data); unfortunately, the dynamics of the MBC in the Fallow plot were not monitored. Nevertheless, this finding indicates that the soil biomass alone may not provide a complete picture of the status of the soil microbiota. It is expected that future studies in this area will shed light on the mechanisms underpinning this observation. However, since both the $\mathrm{C} / \mathrm{N}$ and the $\mathrm{MBC} / \mathrm{MBN}$ ratios under the Fallow regime were comparable to those observed under Cropping or Abandonment, it may be the case that the total carbon and total nitrogen in the Fallow plot declined at the same rate and that there was little change in the microorganism structure within the plot; it has been suggested that the $\mathrm{MBC} / \mathrm{MBN}$ ratio reflects the relative abundance of bacteria and fungi (Wardle, 1992). The Fallow soil management regime thus resulted in the depletion of soil nutrients, reducing soil quality and biological health.

Despite having been abandoned for 20 years after previously being used as cropland, the SOC and TN levels observed in the Abandonment plot were comparable to those observed under Cropping. In sharp contrast, however, the TP and AP levels were significantly lower under Abandonment than under Cropping because of the lack of added $\mathrm{P}$ under the former regime; this suggests that the application of $\mathrm{P}$ is essential for improving or maintaining soil phosphorus fertility (Table 2). The MBC value was higher under Abandonment than under Cropping, suggesting that the abandonment of the cropland had substantial beneficial effects on the activity of microbial organisms; this was probably due to the accumulation of organic $\mathrm{C}$ compounds in the soil surface layer and the lack of tillage. Similar findings have been reported by Landgraf (2001) and Liu et al. (2008). The markedly greater $\mathrm{MBC} / \mathrm{SOC}$ ratio observed under Abandonment compared to Cropping suggests that the former treatment supported a greater quantity of soil microbial biomass per unit SOC than did Cropping over the 20 year experimental period. However, all of the enzymes whose activity was monitored during this work exhibited similar levels of activity under Abandonment and Cropping; the sole exception was invertase, which was significantly less active under Abandonment. These findings are consistent with those of Liu et al. (2008), who also reported that compared to normal fertilization and cropping, abandonment resulted in similar urease activity and decreased invertase activity. Although microorganisms are the main source of enzymes in soils (Tabatabai, 1994), and MBC was markedly greater under Abandonment than under Cropping, the activities of dehydrogenase and alkaline phosphatase were found to correlate strongly with soil P concentrations. The low P fertility observed under Abandonment might thus be expected to affect the enzymatic activity under this regime and could be responsible for the similarity in the level of enzyme activity under Abandonment to that under Cropping. Invertase activity did not correlate significantly with $\mathrm{MBC}, \mathrm{MBN}$, or any soil chemical property other than TP content $(P<0.05)$; similar findings have been reported by Nayak et al. (2007). The significantly lower invertase activity under Abandonment than under Cropping can be explained by the low soil $\mathrm{P}$ level under the former regime. Invertase is primarily involved in C cycling in soil; its low activity under Abandonment is probably indicative of a low rate of $\mathrm{C}$ decomposition and would favor the accumulation of SOC. Overall, the abandonment of cropland increases its suitability as a habitat for colonization by microorganisms, providing a greater quantity and more diverse range of organic substrates and an undisturbed environment; it thus has some beneficial effects and could potentially be used to improve or restore soil quality to some extent. However, it is also possible to maintain healthy soil under Cropping, with similarly advantageous nutrient levels and enzymatic 
activity to those observed under Abandonment. This is partly due to the regular recycling of large root systems and stubble into the soil under Cropping regimes.

\subsection{Nutrient management regimes for cropping systems}

The availability of $\mathrm{N}$ and $\mathrm{P}$ was the primary limiting factor on the agricultural productivity of the investigated soils as measured by the obtained yields of wheat and maize (Table 4). As compared to the control treatment (CK), the application of "unbalanced" fertilization in the N and PK treatments significantly decreased soil $\mathrm{pH}$, but gave similar SOC concentrations, quantities of soil microbial biomass, and enzymatic activities. These fertilization practices did not significantly improve the soil quality; indeed, the large accumulation of unused nutrients they created would be likely to cause environmental problems, such as the formation of $\mathrm{N}_{2} \mathrm{O}$ by denitrification in the $\mathrm{N}$ treated plot or P loss via (sub)surface runoff from the PK plot.

The soil chemical and microbiological parameters observed in soils under the NP, NPK and SNPK treatments were all very similar in most cases, although the $\mathrm{MBC}$ was significantly greater under SNPK than under NP or NPK. This suggests that the application of potassium and the incorporation of wheat straw or maize stalks into the soil had a minor effect over the twenty year period. Marschnera et al. (2003) have similarly observed that the application of NPK in conjunction with the incorporation of residual plant material into the soil did not result in significant differences in SOC, TN, or enzyme activity relative to those observed after NPK treatment alone. However, Monaco et al. (2008) reported significantly higher SOC and TN levels following the incorporation of maize straw $\left(12.6 \mathrm{Mg} \mathrm{ha}^{-1}\right)$ relative to those observed when maize stalks were removed. The MBC levels exhibited very high variation and were therefore indistinguishable under the two regimes examined by these authors, possibly as a consequence of soil drying and rewetting. It is possible that the modest observed response to the incorporation of crop residues in the SNPK treatment relative to the NP and NPK treatments may have been due to the relatively small amounts of wheat or maize straw used in this work $\left(<5.0 \mathrm{t} \mathrm{ha}^{-1}\right)$.

The application of dairy manure in conjunction with NPK resulted in substantial increases in the levels of various soil nutrients and SOC but decreased the soil $\mathrm{pH}$ and the SOC/TN ratio. These findings are generally consistent with those of Li et al. (2008). The pronounced increase in Olsen $\mathrm{P}$ levels under MNPK (242 and $377 \mathrm{mg} \mathrm{kg}^{-1}$ ) suggested that these management strategies may cause $\mathrm{P}$ overload and that the application of manure and chemical $\mathrm{P}$ fertilizer in the quantities used in this work could pose a risk to the environment. The application of manure also clearly increased the soil's MBC content and the ratio of $\mathrm{MBC}$ to SOC, and greatly stimulated enzyme activity relative to that observed under other treatments (Table 2 and 3). Increases in the MBC content of soils following the application of manure have been reported previously (Malik et al., 2013; Tamilselvi et al., 2015). The readily-metabolized carbon and $\mathrm{N}$ in manure is responsible for the observed increases in root biomass and root exudates under the MNPK treatments, both of which are attributable to greater crop growth (Table 4). They are also key factors in the observed increase in microbial biomass. The $\mathrm{MBC} / \mathrm{SOC}$ ratio is a good indicator of the efficiency with which organic $\mathrm{C}$ is transformed into microbial $\mathrm{C}$ and the losses of soil $\mathrm{C}$ during decomposition, and is considered to be a sensitive soil quality parameter that can be used to make comparisons between soils with different organic matter contents (Sparling 1992, 
1997). Of the Cropping regimes examined in our study, the MNPK treatments gave the highest MBC/ SOC ratios, suggesting that the application of manure has a positive influence on the $\mathrm{MBC} / \mathrm{SOC}$ ratio. Similarly, the MNPK treatments also generated the highest enzyme activities observed in this work; this may be related to the high SOC and TN levels in the manure-treated soils, since soils' enzymatic activities are often correlated with their SOC and TN contents (Table 5, Taylor et al. 2002). Higher levels of SOC stimulate microbial activity and therefore enzyme synthesis. In addition, the higher organic matter levels in the MNPK treatments may provide a more favorable environment for the accumulation of enzymes in the soil matrix, since soil organic constituents are thought to be important in forming stable complexes with free enzymes (Marx et al. 2005). The importance of SOC in nutrient cycling was demonstrated by the fact that both $\mathrm{MBC}$ and enzyme activity were found to correlate positively with SOC. Fertilization regimes involving the application of manure are therefore recommended for improving soil biological health and increasing crop productivity, provided that the quantity of organic manure applied can be tuned to minimize the potential environmental risks associated with these approaches.

\section{Conclusions}

The soil management regimes and fertilization practices for 20 years had significant effects on soil chemical and biochemical properties such as soil organic carbon, nitrogen and phosphorus levels, microbial biomass, and enzymatic activities; consequently, the applied management regime has a profound effect on crop productivity. The effect of leaving croplands abandonment had some beneficial effects on soil biological health. Of the cropping systems examined, those involving balanced fertilization of both nitrogen and phosphrus and the application of organic materials in conjunction with chemical fertilizers all generated improvements in the tested soil properties. Long-term application of organic material in conjunction with NPK should be encouraged as practical methods for achieving and maintaining favorable soil chemical and biochemical properties and thereby increasing the productivity of the tested loess soil.

\section{Acknowledgements}

This study was financially supported by the Special Fund for Agro-scientific Research in the Public Interest of China (201203030) and Agricultural Scientific Research Talent and Team Program of China.

\section{References}

Acosta-Martinez. V., Cruz, L., Sotomayor-Ramirez, D., Peirez-Alegria, L. 2007. Enzyme activities as affected by soil properties and land use in a tropical watershed. Applied Soil Ecology. 35, 35-45.

Adriano, M. de L., Gutiérrez, F., Dendooven, L., Salvador-Figueroa, M. 2012. Influence of compost and liquid bioferment on the chemical and biological characteristics of soil cultivated with banana (Musa spp. L.). J. Soil Sci. Plant Nut. $12,33-43$.

Böhme, L., Böhme, F. 2006. Soil microbiological and biochemical properties affected by plant growth and different long-term fertilization. Eur. J. Soil Biol. 42, 1-12.

Bolinder, M.A., Angers, D.A., Gregorich, E.G., Carter, M.R., 1999. The response of soil quality indicators to conservation management.Can. J. Soil Sci. 79, 37-45. 
Bremner, J.M. 1996. Nitrogen-Total. In: Sparks D.L. (ed.) Methods of soil analysis: chemical methods. Part 3. pp. 1085-1122. Madison,Wisconsin,USA.

Burns, R.G. 1978. Soil enzymes. Academic Press, London.

Caldwell, B.A., Griffiths, R.P., Sollins, P. 1999. Soil enzyme response to vegetation disturbance in two lowland Costa Rican soils. Soil Biol. Biochem. 31, 1603-1608.

Caravaca, F.,G. Masciandaro, B., Ceccanti, 2002. Land use in relation to soil chemical and biochemical properties in a semiarid Mediterranean environment. Soil Tillage Res. 68, 23-30.

Emteryd, O. 2002. Chemical and physical analysis of inorganic nutrients in plant, soil, and air. 2nd edition. Umea, Sweden. Grafiska Enheten, SLU.

Guan, S.Y. 1986. Soil enzymes and its methodology. Agricultural Press, Beijing, pp. 274-340.

Landgraf, D. 2001. Dynamics of microbial biomass in Cambisols under a three year succession in north eastern Saxony. J. Plant Nutr. Soil Sci. 164, 665-671.

Li, J., Zhao, B., Li, X., Jiang, R., So, H. 2008. Effect of long-term combined application of organic and mineral fertilizers on microbial biomass, soil enzyme activity and soil fertility. Agricultural Science in China. 7, 336-343.

Liu, E.K., Zhao, B.Q., Li, X.Y., Jiang, R.B., Li, Y.T., So, H.B. 2008. Biological properties and enzymatic activity of arable soils affected by long term different fertilization systems. J. Plant Ecol. $32,176-182$.

Malik, M.A., Khan, K.S., Marschner, P., Fayyazul-Hassan. 2013. Microbial biomass, nutrient availability and nutrient uptake by wheat in two soils with organic amendments. J. Soil Sci. Plant Nut. 13, 955-966.
Marschnera, P., Kandeler, E., Marschner, B. 2003. Structure and function of the soil microbial community in a long-term fertilizer experiment. Soil Biol. Biochem. 35, 453-461.

Marx, M.C., Kandeler, E., Wood, M., Wermbter, N., Jarvis, S.C. 2005. Exploring the enzymatic landscape: distribution and kinetics of hydrolytic enzymes in soil particle-size fractions. Soil Biol. Biochem. 37, 35-48.

Mganga K. Z., Razavi B. S., Kuzyakov, Y. 2015. Microbial and enzymes response to nutrient additions in soils of Mt. Kilimanjaro region depending on land use. Eur. J. Soil Biol. 69, 3340.

Monaco, S., Hatch, D. J., Sacco, D., Bertora, C., Grignani, C. 2008. Changes in chemical and biochemical soil properties induced by 11-yr repeated additions of different organic materials in maize-based forage systems. Soil Biol. Biochem. 40, 608-615.

Murphy, J., Riley, J.P. 1962. A modified single solution method for the determination of phosphate in natural waters. Anal. Chim. Acta. 27, 36-39.

Nayak, D.R., Jagadeesh, Babu, Y., Adhya, T.K. 2007. Long-term application of compost influences microbial biomass and enzyme activities in a tropical Aeric Endoaquept planted to rice under flooded condition. Soil Biol. Biochem. 39, 18971906.

Niu, J.W. 1983. Determination of soil organic matter. In: Li YK (ed.), Routine analytical methods for soil and agricultural chemistry. Science Press, Beijing, pp: 67-74.

Sparling, G.P. 1992. Ratio of microbial biomass carbon to soil organic carbon as a sensitive indicator of changes in soil organic matter. Aust. J. Soil Res. 30, 195-207. 
Sparling, G.P. 1997. Soil microbial biomass, activity and nutrient cycling as indicators of soil health. In: Pankhurst C, Doube BM, Gupta VVSR (eds). Biological Indicators of Soil Health. CAB International, Wallingford, UK. pp. 97-119

Tabatabai, M.A. 1994. Soil enzymes. In: Weaver RW, Angel JS, Bottomley PS (ed), Methods of Soil Analysis, Part 2-Microbiological and Biochemical Properties. SSSA Book Series No.5. Soil Science Society of America, Madison, WI, pp.775-833.

Tamilselvi, S.M., Chinnadurai, C., Ilamurugu, K., Arulmozhiselvan, K., Balachandar, D. 2015. Effect of long-term nutrient managements on biological and biochemical properties of semi-arid tropical Alfisol during maize crop development stages. Ecol. Indic. 48, 76-87.

Taylor, J.P., Wilson, B., Mills, M.S., Burns, R.G. 2002. Comparison of microbial numbers and enzymatic activities in surface soils and subsoils using various techniques. Soil Biol. Biochem. 34, 387-410.
Wardle, D.A. 1992. A comparative assessment of factors which influence microbial biomass carbon and nitrogen levels in soil. Biol. Rev. 67, 321-358.

Witter, E., Kanal, A. 1998. Characteristics of the soil microbial biomass in soils from a long-term field experiment with different levels of C input. Appl. Soil Ecol. 10, 37-49.

Wu, J., Joergensen, R.G., Pommerening, B., Chaussod, R., Brookes, P.C. 1990. Measurement of soil microbial biomass $\mathrm{C}$ by fumigation-extraction: An automated procedure. Soil Biol. Biochem. 22, 1167-1169.

Yang X, Ren W, Sun B, Zhang S. 2012. Effects of contrasting soil management regimes on total and labile soil organic carbon fractions in a loess soil in China. Geoderma. 177-178, 49-56.

Zhang, Y.L., Chen, L.J., Chen, Z.H., Sun, C.X., Wu, Z.J., Tang, X.H. 2010.soil nutrient contents and enzymatic characteristics as affected by 7 -year no tillage under maize cropping in a meadow brown soil. J. Soil Sci. Plant Nut. 10, 150-157. 